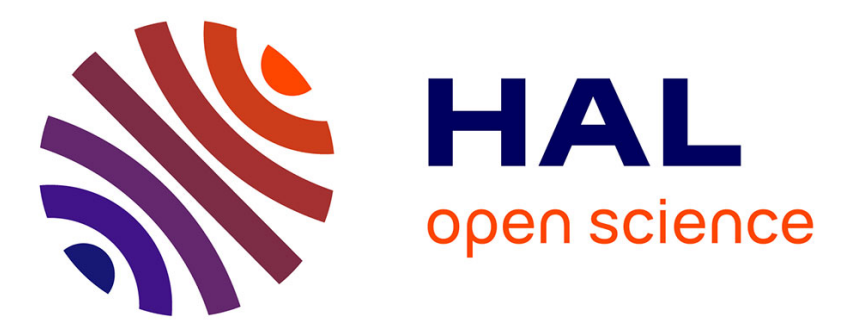

\title{
Postero-Inferior Pedicle Surgical Technique for the Treatment of Grade III Gynecomastia
}

Nicolas Bertheuil, Christian Herlin, Raphael Carloni, Sophie Thienot, Nathalie Kerfant, Eric Watier

\section{- To cite this version:}

Nicolas Bertheuil, Christian Herlin, Raphael Carloni, Sophie Thienot, Nathalie Kerfant, et al.. Postero-Inferior Pedicle Surgical Technique for the Treatment of Grade III Gynecomastia. Aesthetic Plastic Surgery, 2017, 41 (3), pp.749-750. 10.1007/s00266-017-0865-4 . hal-01560208

HAL Id: hal-01560208 https://hal-univ-rennes1.archives-ouvertes.fr/hal-01560208

Submitted on 12 Oct 2017

HAL is a multi-disciplinary open access archive for the deposit and dissemination of scientific research documents, whether they are published or not. The documents may come from teaching and research institutions in France or abroad, or from public or private research centers.
L'archive ouverte pluridisciplinaire HAL, est destinée au dépôt et à la diffusion de documents scientifiques de niveau recherche, publiés ou non, émanant des établissements d'enseignement et de recherche français ou étrangers, des laboratoires publics ou privés. 


\section{Postero-inferior pedicle surgical technique for the treatment of grade III gynecomastia}

Nicolas Bertheuil, MD ${ }^{1,2,3}$, Christian Herlin, $\mathrm{MD}^{4}$, Raphael Carloni, MD ${ }^{5}$, Sophie Thiénot, $\mathrm{MD}^{1}, \mathrm{PhD}$, Nathalie Kerfant $\mathrm{MD}^{6}$, Eric Watier, M.D, $\mathrm{PhD}^{1}$.

1 - Department of Plastic, Reconstructive and Aesthetic Surgery, South Hospital, University of Rennes 1, Rennes, France.

2 - INSERM UMR U1236 MICMAC, University of Rennes 1, Rennes, France.

3 - SITI Laboratory, Etablissement Français du Sang Bretagne, Rennes University Hospital, Rennes, France.

4 - Plastic and Reconstructrive Surgery and Burns Unit, CHU Montpellier, Montpellier, France

5 - Plastic and Reconstructrive Surgery, CHU Rouen, Rouen, France.

6 - Department of Plastic, Reconstructive and Aesthetic Surgery, CHU Brest, Brest, France.

Corresponding author:

Dr Nicolas Bertheuil

Department of Plastic, Reconstructive and Aesthetic Surgery, Hospital Sud, Rennes, France.

16 Boulevard de Bulgarie, 35200, Rennes

Phone: 0033299267168

Fax: 0033299266718

E-mail: nbertheuil@gmail.com 
Financial disclosure and conflicts of interest

The authors received no funding support for the research of this article and declared no potential conflicts of interest with the respect to the research, authorship and/or publication. 


\section{Postero-inferior pedicle surgical technique for the treatment of grade III gynecomastia}

We have read with great attention the comments concerning our article ${ }^{1}$ and we would like to thank the authors for the interest they have shown in our new operative technique for grade III gynecomastia.

This letter allows to our team to reiterate our opinion on the place of the postero-inferior pedicle technique in the treatment of gynecomastia. For the grade III-patients, the main surgical treatment is the free transplantation of the nipple-areola complex which permits to correct skin excess and ptosis of the areola. However, this technique leads to a nipple areola complex insensitive, a risk of hypopigmentation and a retraction of the areola. All these problems are avoided with the posteroinferior pedicle technique which is particularly adapted in overweight patients. In this targeted population the risk of complications is increased. It's now well described that the use of extensive concomitant liposuction ${ }^{2,3}$ in body contouring surgery achieves good aesthetic results and decrease the complication risk.

The liposuction enables to preserve the connective tissue. Moreover, we have recently demonstrate by flow cytometry and confocal microscopy that inside the preserved connective tissue which contain nerves, lymphatic and blood vessels, a significant part of the microvascular network was also preserved. This explains probably the low complication rate of liposuction-assisted body contouring technique by a possible preservation of the physiology of the remaining tissue ${ }^{4}$ even if this specific point must still be proven. Further studies are necessary to better understand the physiology and functionality of the remaining vessels.

Our technique was based on our experience in the massive weight loss patients, and permits to correct grade III gynecomastia and also major chest deformations following massive weight loss integrating an upper bodylift (Figure 1).

As highlighted by the authors the patient expectations are very important and physician's goal is to understand them, explain expected results to the patients as well as limitations such as scarring. In our 
daily practice we perform drawing preoperatively in standing position in order to the patients project the result and accept the surgical act accordingly. We perform two consultations before operating.

However, we do not agree with the authors when they say that less visible scarring may be preferable in the majority of cases of severe gynecomastia. The authors explain that the periareolar scarring ${ }^{5}$ is sufficient for a majority of severe ptosis ${ }^{6}$. We are agree that this technique can treat grade II and III with small ptosis but it seems very difficult to correct major skin excess such as in our series. To illustrate our remarks, we would like to report our experience in two cases. In the first case, we present a 19 years-old obese patient $(\mathrm{BMI}=35.8)$ with good result at one post-operative year after posteroinferior pedicle and upper body lift (Figure 1). In the second case, we present an insufficient result on the same type of patient with periareolar technique (Figure 2). We think that the technique described by the authors ${ }^{5}$ doesn't allow to get a predictable results in all cases of grade III gynecomastia.

In conclusion, we thank the authors for their interest to our technique and their experience about surgical treatment of gynecomastia which permits better understanding and resolution of this problem.

\section{REFERENCES}

1. Thiénot S, Bertheuil N, Carloni R, Méal C, Aillet S, Herlin C, Watier E. Postero-Inferior Pedicle Surgical Technique for the Treatment of Grade III Gynecomastia. Aesthetic Plast Surg. doi: 10.1007/s00266-017-0810-6.

2. Bertheuil N, Chaput C, De Runz A, Girard P, Carloni R, Watier E. The Lipo-Bodylift: A new circumferential body-contouring technique useful after bariatric surgery. Plast Reconstr Surg. 2017 Jan;139(1):38e-49e.

3. Bertheuil N, Thienot S, Chaput B, Varin A, Watier E. Quality-of-Life assessment after medial thighplasty in patients following massive weight loss. Plast Reconstr Surg: 135: 67e-73e. 
4. Bertheuil N, Chaput B, Berger-Muller S, et al. Liposuction Preserves the Morphological Integrity of the Microvascular Network: Flow Cytometry and Confocal Microscopy Evidence in a Controlled Study. Aesthet Surg J. 2016;36(5):609-18.

5. Huang TT, Hidalgo JE, Lewis SR. A circumareolar approach in surgical management of gynecomastia. Plast Reconstr Surg. 1982 Jan;69(1):35-40.

6. Innocenti A, Melita D, Mori F, Ciancio F, Innocenti M. Management of Gynecomastia in Patients With Different Body Types: Considerations on 312 Consecutive Treated Cases. Ann Plast Surg.

Figure legend:

Figure 1: In the right column: pre-operative view in an obese patient, front side, profile side and back side. In the left column: post-operative view at one year.

Figure 2: In the right column: pre-operative view, front side, profile side and back side. In the left column: post-operative view at Six months. 


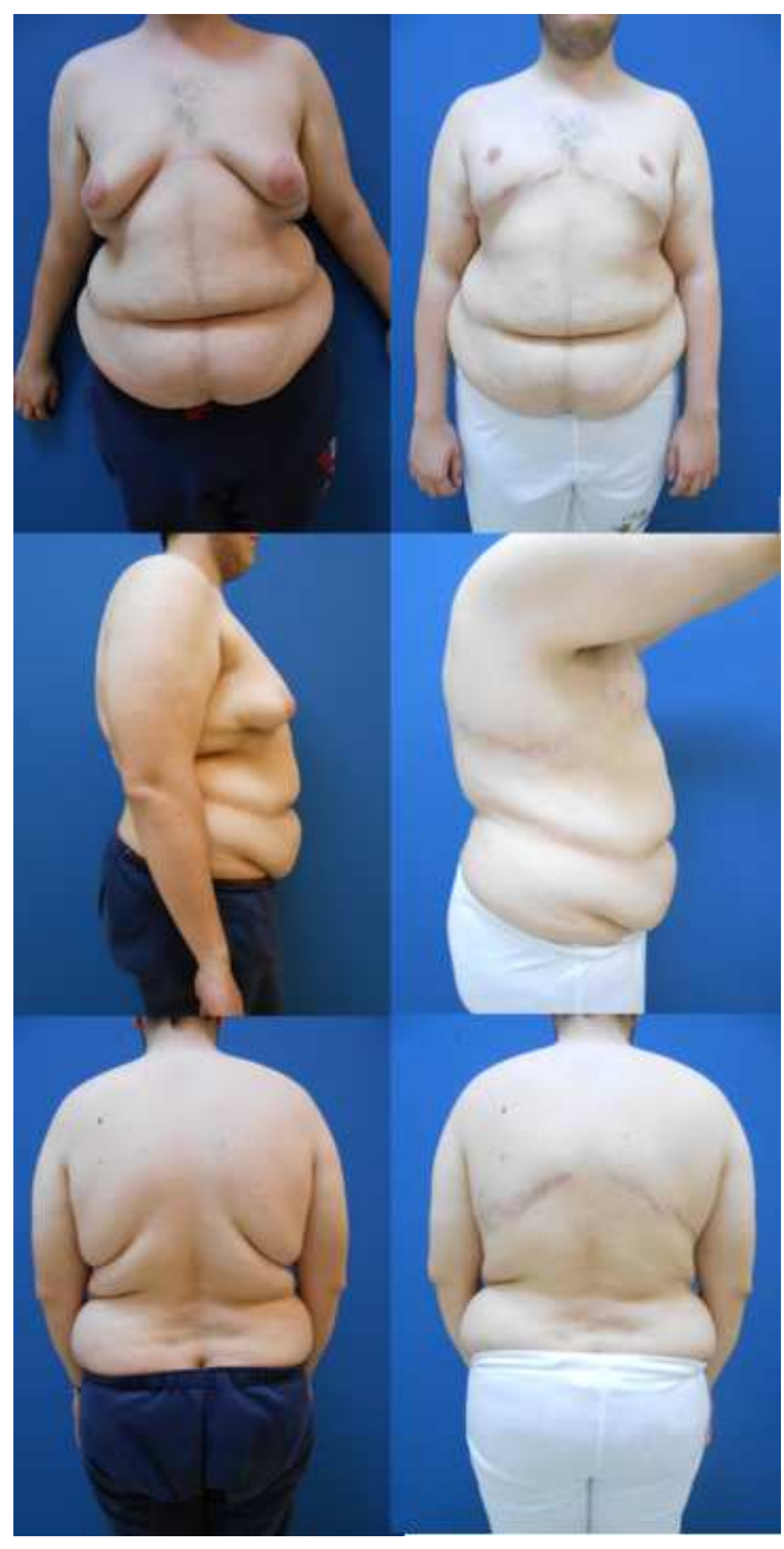



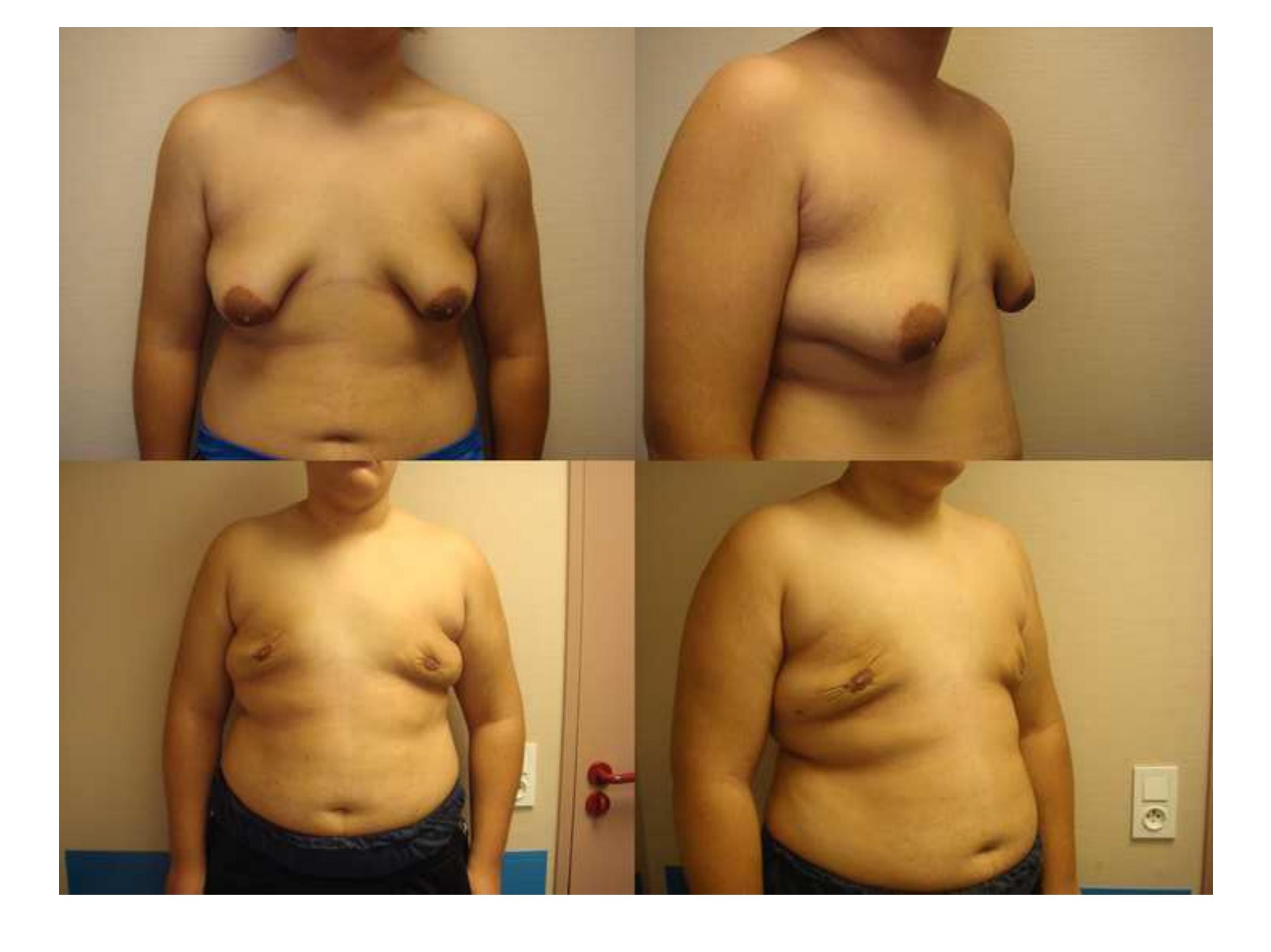